\title{
Post-Secular and Post-Metaphysical Forms of Philosophical-Legal Thinking: Global and Post-Soviet Trends
}

\author{
Marina D. Fominskaya \\ Stavrapol Institute of Cooperation (branch) of Belgorod University of Cooperation, Economics and Law \\ Email:k_fp3@mail.ru
}

Doi:10.5901/mjss.2015.v6n5s3p232

\section{Abstract}

This article discusses the basic philosophical and legal approaches, justifying post-secular model of correlation and interaction of religion and law, reason and faith, and examines the solidarity approach to law and development of legal systems in postsoviet space. This paper describes the crisis of classical secular model of social organization and characterizes new postsecular and post-metaphysical forms of thinking and practice. Normative differentialism, communication theory, sociocultural approach, agonistic model, solidarity approach are allocated and examined in the quality of philosophical-legal trends. The author proves that in area of the post-Soviet Union dominates solidarity form of political-legal thought, in which solidarity is considered as a qualitative state of the social system, characterized by integrity and unity, suggesting a mechanism for sustainable development, orienting all occurring social processes and events on the achievement of consensual goals, the reproduction of socio-cultural identity and pivotal (axled) spiritual and moral foundations of the social system.

Keywords: faith, state, post-metaphysics, law, human rights, legal consciousness.

\section{Introduction}

Within the framework of philosophical and legal debates of the XX century the dominant issue was the rationale reducing of the role and significance of spiritual, moral and, above all, the religious foundations of law and state.

Today this position is placed in question, in domestic and foreign philosophy of law in understanding of the religious and other spiritual and moral experience is approved a radical shift, the value of the last is in the formation of normative and institutional bases of the state and legal organization of society and its development.

Moreover, the crisis of normative Western concepts, such as a secular state and multiculturalism, the practice of "extrication" of public law communication from religious and ethical, as normative pluralistic and private foundations of interaction between individuals, today, objectively require new ideological and normative theories and concepts. In other words, this crisis initiates new post-secular and post-metaphysical forms and practices of thinking. At the same time postsecular is not a "return" of religious or "theological revolution" (D. Janice), but rather the formation of a new (post-modern) "uncertainty about the correlation between religious - secular" (Kyrlejev A., 2011, p. 101).

\section{Literature Review}

Modern specialized literature emphasizes that the cardinal turn in the understanding of social and legal organization of society and a paradigm shift in the philosophical and legal thinking, lead to the formation of new post-secular and postmetaphysical orientations (states) of development (Andrey Y. Mordovcev, Tatyana V. Mordovceva \& Aleksey Y. Mamichev, 2015). In this qualitatively new condition of mass and professional legal consciousness is formed a stable belief in "inaccuracy and haste to the conclusions which were made on the basis of the once-popular theories of secularization, arguing that modernization and secularization go hand in hand - the more of one, the more of another" (Uzlaner D., 2011, p. 3).

Today, in scientific publications, is clearly seen:

- $\quad$ first, change of the "ethos" of philosophical and legal studies, bases and forms of modern organization of communication and interaction in society (P. Sztompka, 1999);

- secondly, the formation and new ideological-conceptual and programmatic variations of the post-secular and post-metaphysical descriptions of reality (A. Giddens, 1990).

During the entire XX century in the Western philosophical and theological thought was dominating the principle of 
consistency of belief and knowledge, substantiated by John Paul II in the Encyclical "Fides et ratio". This principle gave a powerful impulse to the development of Neo-Thomist, religious-humanistic (e.g., the concept of "integral humanism" (Maritain J., 2000 \& Magsumov, 2013) and other Christian philosophical and legal concepts (Ter-Akopov, A. A., and Tolkachenko A., 2002). This period was characterized by a reinterpretation of the classical principles of gentilesse, formulated by the Enlightenment, the development of dialogue between positivist and Christian philosophical dimension of law (J. Gray., 2003). For example, it was settled that "philosophy of law (modern and ancient) examines the relation between existing legal norms (and the projects) from the point of view of the relation between the highest norms of human morality, and also helps to find something the most significant and similar in the various "national" laws and legal systems" (P. D. Barenboym, 2012).

There have been significant developments in the field of "Justification of the law" (the influential work of the theologian K. Barth) as a high spiritual and moral essence; his reconciliation with religious principles, dogmas and norms (Bart K., 2008). In other words here takes place the justification of the state legal organization as "intimate life of a Christian in God and in civic duty... one does not contradict the other, but on the contrary, one may exist to act in parallel to another" (Bart K., 2008, p. 8).

It is no coincidence that one of the significant and fundamental works is the study of a well-known lawyer of G.J. Berman - "Faith and law: the reconciliation of law and religion" (Berman, G. J., 1999). In this aspect of the reconciliation of right and law - it was noted that in the basis of all legal systems lays the principle of justice, the source and the content of which is impossible to change without recourse to religious consciousness, and many legal ideas, practices and technologies as a "sample" had a theological models (Heffe O., 2007).

Modern uncertainty in the ratio of religious secular in legal consciousness causes the lack of agreement about basic values and norms of the regulators, their roles and significances in the coding of social relations, legal, political, economic and other procedures of interaction. This uncertainty, as noted, stimulates the development of various (sometimes very controversial) philosophical and legal concepts. Today, in Western European discourse can be identified several most influential philosophical and legal constructions that offer post-secular model of correlation and interaction of religion and positive law, the religious and the rational in the legal culture of the society.

\section{Methods and Materials}

Post-secular bases of philosophical legal foundations are related to understanding the qualitatively different state of society, principles of its organization and normative bases for social interaction. In its turn, post-metaphysical of such studies are stipulated by the crisis of classical rationality and the formation of new principles and perspectives of philosophical and legal studies. The latter is associated with "exit for" classical principles of normativity, where neither religious tenets nor principles of rationality do not have any priority, and the post-secular society organization and communication is possible on the basis of new forms of post-normalization.

We assume from the following theoretical and methodological promise: the subversion of moral "axis", around which was developing a variety of value-normative systems and hierarchies, was ensured social cohesion and social solidarity, leads to a rather pessimistic forecasts, to the impossibility of any holistic modeling of social development. Moreover, the liberal democratic discourse in the XXI century objectively initiates sustainable "trend "non-development", the rejection of the development. The prospect of such "non-development", - as rightly says A. N. Okara - in the foreseeable future can become a "new barbarism", archaism and degradation of the vast majority of humanity, including Russia and post-Soviet space" (Okara A. N., 2010 \& Magsumov, 2014).

As such an alternative, in our opinion, can act solidaric state and legal system based on Christian values and normative system.

\section{Results and Discussions}

Currently there are a number of modern philosophical and legal areas, which form the basic paradigm setups in the correlation between the secular and the religious in state and legal organization of society.

\section{1 «Regulatory differentialism».}

This philosophical and legal school arguments the necessity of the formation of a new post-secular normativity and global (universal) design of a new form of identification and socio-legal consent, "exempted" from the secular principles (nationality, ethnicity, state sovereignty, etc.), and "religious universalism" (J. Habermas, 2008). When is justifying the 
formation of a place of origin abstract and universal normative systems (instead of the collapse of the principles of multiculturalism and the classical system of international law) which impose on all participants of the communication process.

On the other hand, it is argued that the secular philosophical and legal thinking has in post-secular society no right to criticize religion and to make a final judgment. On the contrary, in the framework of this school differentiation of normatively, a clear definition of reasonable limits, separating religiosity and rationality is justified. In this respect necessary is "the development of such attitude to other religions and worldviews, which will allow their legitimate presence in the same discursive space... autonomous process of secular science should cease to contradict the faith" (Uzlaner D., 2011, p. 4).

Such post-normatively supposes construction of a new model of sociality, based on rational-communicative interaction and the achievement of universal moral consent. As such form of socio-legal consolidation and moral consent acts the European identity "which initially carries something constructed, it is regarded as a product of public activity" (J. Habermas, 2008, p. 45). In addition, this form of socio-legal and moral-ethical communication requires the unconditional acceptance of the general system of nominative limitations because this system "works only if all participants are ready to fully comply with the restrictions imposed on them. But these restrictions make sense to apply only if there is agreement about the foundations of modern society" (Uzlaner D., 2011, p. 6).

\subsection{Communicative theory argues that instead of traditional hegemonies claiming of "absolute truth" by political ideology or religious dogma, in post-secular world happens conventional process of communicative consent.}

Within the philosophical-legal researches of this school it is argued that in the modern world cannot exist "immutable" and "consistent" regulatory systems, and the only possible consensus is "through permanently open and free communication" (mark van Huk., 2012). Namely this open communication and consensual agreement act as an alternative to the classic rationalism and religious dogmatism applying for an unambiguous interpretation of the truths.

This philosophical and legal position, unlike the previous, justifies the diversity of the legal world, asserts that there is no "clear legal facts" outside of culture and moral system: "whole world of diverse points of view is hidden in the law and in legal language." Each culture, according to Mark van Huk, is a combination of various elements, their interrelated interaction. Thus, the right is connected with the society, existing in it value and norm and moral systems. And if a variety of socio-normative regulators are in harmonious interaction, it is not the fact of a new religious or moral-ideological hegemony over the world of law, but a "symptom of the harmonious development of society and great luck for it... because right is never just a tool in the hands of the state, it, in fact, should carry the "higher plan" of development, predetermined law and order, in connection which the state and its management, in its turn, are associated with instrumental role, i.e. are the means of achieving it, are constantly improving legal schemes" (Maltsev G. V., 2007).

\subsection{In the framework of socio-cultural school of philosophical-legal studies}

In the framework of socio-cultural school of philosophical-legal studies it is argued that post-secular normativity it is not just a set of effective principles, tools and institutions, claiming rationally organized procedure of relationship, but, above all, a holistic way of life, involving the convergence of religious and legal regulatory systems. That is why, for example, from the point of view of J. Gray, a universal discursive matrix indicating a relationship of reason and faith, a single idealtypical model of spiritual, moral, political, economic and social relations can not exist, but "there is a diversity of historical forms, each of which is rooted in the fertile soil of culture, related to certain society". UAnd therefore normative systems "do not reflect the national culture or inconsistent to it, can be neither legitimate nor stable: they are either are modified or are rejected by the people whom they are imposed" (Gray, J., 2003, p. 115).

Therefore, in post-secular society in the forefront should be socio-cultural factors and traditional value and normative systems that return to modern societies stability and successive evolution. And namely the recognition of the priority of the last "allows the adherents of various cultural traditions reflect these traditions in legal orders, which they must obey without resorting to separatist actions" (Gray, J., 2003, p. 264).

\subsection{Agonistic regulatory model}

In the framework of this model it is argued that political and legal phenomena of the social world are universal, however, their specific forms of implementation are radically different. It is emphasized that the decline of the social power of religious ideas and institutions, and also the decline of religious beliefs and practices are not inevitable process of 
modernization. For example, Chantal Muff indicates that the theory according to which modernization and secularization are interrelated is a myth. Fault is the claim that contemporary processes of modernization lead to the decline of religious beliefs and practices (Muff Sh., 2009, p. 69).

Consequently, post-secular world should proceed from the idea of "multiple versions of modernity and agree that the way of the West is not the only possible and legitimate that non-Western societies may follow different routes, according to the specifics of their cultural traditions and religion" (Muff Sh., 2009, p. 71). It should also be recognized that the post-secular world is an "infinite gamw of differences", the conflict and the confrontation of various forms, secular and religious (Laclau E., 2003). Therefore, it is necessary to leave "the illusory hope of a political unification of the world, we must advocate for the establishment of an agonistic multi-polar world, organized around a few large territorial units with different cultures, religions and values" (Muff Sh., 2009, p. 63).

In this respect, the agonistic model is based on "conflict agreement", involving the divergence in ethical, religious, political and legal principles of society. The "return" of religious, moral and ethical in the social construction of the social orders comes from the fact that "other cultures define the samehood in a different way". In these cultures steadily dominate "their ideas about human dignity and the conditions for a fair social structure" (Muff Sh., 2009, p. 68). While the state legal community, of many non-Western social systems, is organized and is operated on the harmonious combination of religious norms and positive law, sacred and secular values.

In addition, in many societies there are so-called "functional equivalents of human rights", which are closely intertwined with religious norms and are inseparable from them; and are more efficient and effective than the Western European concept of human rights and freedoms. Consequently, according the conclusion of the Shantal Muff, the strong satement that "moral progress requires the adoption of the Western model of liberal democracy, as only its frame ensure respect for human rights, should be rejected" (Muff Sh., 2009, p. 68).

\subsection{Solidarity socio-spiritual and political-legal organization of society.}

Solidarity should be seen as a form and the principle of social existence and organization of community life. Thus, the form is focuses on mutual agreement and interaction of unique social actors, groups and organizations, in the framework of reproducing (from generation to generation) ща socio-cultural and moral integrity. In its turn, the principle, according to fair comment of A. N. Okara, is aimed at ensuring of social (political, legal, economic, etc.) unity and stability (balance, harmony, etc.), involves "the pooling of resources and capabilities of the entities to achieve common goals", where "the interests of each of the actors are in balance with the interests of society" (Okara A. N., 2010).

This ideological and theoretical-methodological position serves as alternative to the Western socio-political and legal projects that are dominating in the XX century. Thus, in the framework of the liberal democratic project of the organization metaphysical principles of social inclusion and extralegal bases of development of legal system of society are leveled. Respectively where is no place for metaphysical and extralegal bases, genuine spiritual and moral tradition of the society is destroyed, remains only material reality (movable, changeable, situational, etc.), and the only significant issues are technologies of control of these changes, the creation of a common (universal) framework, connecting on a temporary basis personalized will, aspirations, interests. In neoliberal constructions of the XXI century has already been rejected any social totality, now as "excessive" is considered the totality of the sovereign state and legal organization.

Traditional totality of a juridico-political organization, created (constructed) and represented by the state, is replaced today by mobile globalonline social organizations, which are no longer directed by solidary aspirations, and operate mobile (change and become more complex, break up and organize themselves). Thus the limits of their political and legal activity is no longer associated with the socio-cultural identity and state-sovereign rationing, and are only subjected to a common (standardized) "rules of rational communication and universal neo-liberal "constitutional legal identity" (Mamichev A. Y., 2014).

In its turn, within the framework of solidarism all actors of political and legal life function not on the basis of atomization (individualization), but in the framework of a consensual political-legal regime. Here, all actors of specific holistic social system are citizens, ethnic groups, religious denominations, social groups and organizations, political parties, businesses, etc. "have real legal and socio-political subjectivity, on the basis of what their rights, capabilities and interests can be consolidated and solidarized to achieve consensual goals in the social framework of different scales (local, national, global)" (Okara A. N., 2010).

From our point of view solidarism in socio-cultural pattern and political and legal organization of society can be meaningfully described by a range of characteristics. In other words solidarism acts as a certain state of the ideologicalconceptual framework and social technologies.

1. Solidarism as a qualitative state of the social system, characterized by integrity and unity, suggesting a 
mechanism of sustainable development, which directs all processes and events on the achievement of consensual goals, the reproduction of socio-cultural identity and rod (axial) spiritual and moral foundations of the social system. Namely the latter allow to ensure the integrity, unity and stability of a particular social system under various transformations, changes and reorganizations in the life of society on the various stages of its development. Moreover, integrity is considered as a qualitative condition of life of the people in his space-time (i.e., the integrity of the evolution of legal, political and socio-cultural life of the people, despite the various disasters, "crashing", the radical transformations that occur during development), spiritual moral (whole national system of beliefs, ideas, symbols, images, attitudes, stereotypes, etc.), geographical and climatic (spatial, environmental and climatic specifics of the deployment of social processes and socio-legal interaction determining public legal forms of organization and modes of interaction between the parts, elements) unity.

2. Solidarity stands out as the ideological-conceptual (extralegal) basis for the development of a national system of law based on Christian values and normative system. In the "Basic social concept of the ROC" is stated that "A right is recognized to be a manifestation of a single divine law of the universe in the social and political sphere... ... Национальное право несовершенно, ибо несовершенен и грешен любой народ. The law of a particular country is the private version of the common worldview of the law, characteristic of a given nation... The National law is imperfect, as imperfect and sinful is any law. However, it establishes a framework for people's life if it translates and adapts the absolute truth of God to a specific historical and national existence" (Basics of the social concept of RICS).

Ideological and conceptual foundations of legal policy of any state legitimise specific historical functioning of the various social, political, legal institutions and systems (Berman, G. J., 1999). Therefore, in the ideological and conceptual basis of solidarism the idea of integrity expresses something more, beyond the specific law and any state function. "For the jurisprudential differences - notes K. Schmidt - legal types of thinking of much larger and profound importance is the fact that a distinction is in alleged and fundamental views about a certain consistent order in the ideas of what can be considered as a normal situation, who is a normal person and which are considered in the legal life and legal thought as a typical specific pieces of life... Without a permanent, inevitable and necessary specific assumptions there is neither legal theory nor the practice of law (emphasis added - M. F.)" (K. Schmidt, 2010, p. 22-23).

At various stages of national solidarity ideological and conceptual framework was expressed in the various doctrines and concepts ("conciliarism", "symphonic", "Slavic collectivism", "unity", "guaranteeing state", "right awareness", "corporate state", "territorial unity", "social anarchism", etc.) and had a pivotal importance for the development of domestic legal and political system.

3. Solidarism acts as socio-legal technology and management practice aimed at harmonization of diverse social interests and needs. In this framework for solidarity legal policy the most important management objective is to ensure harmonization (identification) of the interests of personality, society, state. In modern doctrinal legal documents this solidarity direction is normatively expressed in the definition of the national interest. Thus, in specialized literature has rightly pointed out that national interest is solidarized (specific, generalized and harmonized) interests of all key actors of integral the Russian socio-cultural system (Ovchinnikov A. I., 2014).

In the managerial aspect solidarism is expressed not in "ideocratic domination" (P. Sorokin) of religious values, but in development on the basis of religious and moral ethics of the mechanisms, institutions and public law practices, aimed at the harmonization of interests and diverse (ethnic and national) values, functional orientation of which is caused by the formation of an integrated and sustainable development of the social system, creation of "harmonized sociality" and "good society" (Fedotova V. G., 2005).

\section{Conclusion}

5.1. Modern practice of "deliverance" of public law communication from religious and ethical, as normative pluralistic and private foundations of interaction between individuals, today, objectively require new ideological and normative theories and concepts. This crisis initiates new post-secular and post-metaphysical forms and practices of thinking. Modern uncertainty in the ratio of religious secular in the legal consciousness causes the lack of agreement about basic value and norm regulators, their roles and significances in the coding of social relations, legal, political, economic and other procedures of interaction. This uncertainty encourages the development of different (sometimes very controversial) philosophical and legal concepts.

5.2. In modern philosophical and legal thought has clearly formed a set of concepts and approaches that form the post-secular and post-metaphysical forms of thinking: 1) regulatory differentialism - legal philosophical school, which 
argues the need for the formation of a new post-secular normativity and global (universal) design of a new form of identification and socio-legal consent, "liberated" from the secular principles (nationality, ethnicity, state sovereignty, etc.), and from "religious universalism"; 2) communicative theory argues that instead of traditional hegemony claiming by political ideology or religious dogma "absolute truth" in post-secular world comes conventional process of communicative consent; 3socio-cultural school of philosophical-legal researches substantiates that post-secular normativity, it is not just a set of effective principles, tools and institutions, claiming rationally organized relationship, but, above all, a holistic way of life, involving the convergence of religious and legal systems;4) agonistic approach proves that the political and legal phenomena in the social world are universal, however, their specific forms of implementation is radically different. Thus, here it is emphasized that the decline in the social power of religious ideas and institutions, and the decline of religious beliefs and practices are not inevitable process of modernization; 5) Solidary approach focuses on vzaimosoglasovannyie and unique interaction of social actors, groups and organizations, in the framework of reproducing (from generation to generation) socio-cultural and moral integrity.

5.3. In the post-Soviet space dominates solidary form of political-legal thought, in which solidarity is thought as a qualitative state of the social system, characterized by integrity and unity, suggesting a mechanism for sustainable development, orienting all occurring social processes and events on the achievement of consensual goals, the reproduction of socio-cultural identity and rod (axial) spiritual and moral foundations of the social system. Thus, the solidarism acts: on the one hand, as the ideological and conceptual (extralegal) basis for the development of a national system of law based on Christian values and normative system; and socio-legal technology and management practices aimed at harmonization of diverse social interests and needs.

\section{References}

Barenboym, P.D. (2012) Biblical beginning of philosophy of law // Legislation and economy. № 2. pp. 9-17.

Bart, K. (2008) Justification and right. M. pp. 268.

Berman, G.J. (1999) Faith and law: the reconciliation of law and religion. M. pp. 430.

Gray, J. (2003) Wake of the enlightenment: politics and culture in the twilight of modernity. M. pp. 345.

Krilejev, A. (2011) Post-secular: a brief interpretation // Logos. № 3 (82). pp. 100-106.

Barenboim, P.D. (2012) beginning Biblical philosophy of law // Legislation and economy. No. 2. pp. 9-17.

Bart, K. (2008), the Justification and right. M. pp. 268.

Berman, G.J. (1999) Faith and law: the reconciliation of law and religion. M. pp. 430.

Gray, J. (2003) Wake on education: policy and culture in the twilight of modernity. M. pp. 345.

Kuliev, A. (2011) post-secular: a brief interpretation // Logos. No. 3 (82). pp. 100-106

Llaklau, E. (2003) The inability of society Logos. № 3-4 (39). pp. 54-57.

Maltsev, G.V. (2007) Social foundations of law. M. pp. 800.

Mamichev, A.Y. (2014) State power in the XXI century: contemporary political projects of the simulation // the State power and local selfgovernment. № 1. pp. 3-9.

Maltsev, G.V. (2007) Social foundations of law. M. pp. 800.

Mamishev A.Y. (2014) State power in the twenty-first century: contemporary political projects of the simulation // the State power and local self-government. No. 1. pp. 3-9.

Mariten, J. (2000) The individual and the state. Moscow: Idea-Press. pp. 320.

Magsumov, T. A. (2013). Educational excursions in technical schools of pre-revolutionary Russia. Bylye Gody, 27(1), 52-60.

Mark, van Huk. (2012) Law as communication. SPb. pp. 292.

Muff, Sh. (2009) Democracy in a multipolar world // Prognosis M.: the territory of the future.№2(18). pp. 59-71.

Ovchinnikov, A.I. (2014) Russia's national security in a networked war // Philosophy of law. №2 (63). pp. 58-63.

Marian, J. (2000) the individual and the state. Moscow: Idea-Press. pp. 320.

Mark, van hook. (2012), Law as communication. SPb. pp. 292.

Muff, S. (2009) Democracy in a multipolar world // Prognosis M.: the territory of the future. No. 2(18). pp. 59-71.

Ovchinnikov, A.I. (2014) Russia's national security in a networked war // Philosophy of law. No. 2 (63). pp. 58-63.

Okara, A.N. (2010) Social solidarity as the basis of a new "microstraining" project. Access mode: http://www.intelros.ru/pdf/synergia _09_10/2.pdf.

Magsumov, T. A. (2014). Main approaches to the study of historical and educational process. Bylye Gody, 34(4), 720-726.

The basics of social concept of the RICS. Access mode: http://www.patriarchia.ru/db/text/141422.html

Ter-Akopov, A.A. \& Tolkachenko A. (2002) The biblical commandment: Christianity as metaright modern legal systems // Russian justice. № 6. pp. 59-69.

Okara, A.N. (2010) Social solidarity as the basis of a new "microstraining" project. Available at: http://www.intelros.ru/pdf/synergia 09_10/2.pdf.

The basic social concept of the RICS. Available at: http://www.patriarchia.ru/db/text/141422.html.

Ter-Akopov, A.A. \& Tolkachenko A. (2002) the Biblical commandment: Christianity as metaright modern legal systems // Russian justice. 
No. 6. pp. 59-69.

Uzlaner, D. (2011) Introduction to post-secular philosophy // Logos. № 3 (82). pp. 3-32.

Hamberas, Y. (2008) Split West. M. pp. 320.

Fedotova, V.G. (2005) A good society. M. pp. 544.

Heffe, O. (2007) Justice: Philosophical introduction. M. pp. 192.

Shmidt, K. (2010) The state and political form. M. pp. 272.

Uslaner, D. (2011) Introduction to post-secular philosophy // Logos. No. 3 (82). pp. 3-32.

Habermas, J. (2008) Divided The West. M. pp. 320.

Fedotova, V.G. (2005) the Good society. M. pp.544.

Heffe, O. (2007) Justice: a Philosophical introduction. M. pp. 192.

Schmidt, K. (2010) the State and political form. M. pp. 272.

Alexey, I. Ovchinnikov, Alexey Y. Mamychev \& Svetlana F. Litvinova (2015) Extra-Legal and Shadow Functioning of Public Authorities // Mediterranean Journal of Social Sciences. MCSER Publishing, Rome-Italy. Vol 6. No 3. pp. 387-394.

Andrey, Y. Mordovcev, Tatyana V. Mordovceva \& Aleksey Y. Mamichev (2015) The Convergence of Law: The Diversity of Discourses /I Mediterranean Journal of Social Sciences. MCSER Publishing, Rome-Italy. Vol 6. No 3. pp. 262-270.

Alexey, Y. Mamychev, Evgeniya Y. Kiyashko \& Alla A. Timofeeva (2015) Conservative Political Transformation Projects of the Russian Government: The Main Discourses of Contemporaneity // Mediterranean Journal of Social Sciences. MCSER Publishing, RomeItaly. Vol 6. No 3. S. 2. pp. $389-396$.

Giddens, A. (1990) The Consequences of Modernity. Stanford University Press, pp. 240.

Sztompka, P. (1999) Trust: A Sociological Theory. Cambridge University Press, pp. 214. 